\title{
Correlation between the expression of IL-18 and deep venous thrombosis
}

\author{
GUANGDI LI ${ }^{1}$, RUDAN ZHOU ${ }^{2}$, XUELING ZHAO ${ }^{2}$, RIGUANG LIU ${ }^{1}$ and CHUAN YE ${ }^{1}$ \\ ${ }^{1}$ Department of Orthopedics, The Affiliated Hospital of Guizhou Medical University, Guiyang, \\ Guizhou 550004; ${ }^{2}$ Department of Orthopedics, The First Affiliated Hospital of Kunming Medical University, \\ Kunming, Yunnan 650032, P.R. China
}

Received January 8, 2018; Accepted May 9, 2018

DOI: $10.3892 / \mathrm{ijmm} .2018 .3682$

\begin{abstract}
The present study aimed to investigate the effect of the expression of interleukin (IL)-18 and related markers on deep venous thrombosis (DVT) to examine their correlation. Sprague-Dawley rats of different models were established and were randomly assigned into three groups. The expression of IL-18, nuclear factor (NF)- $\kappa \mathrm{B}$ and von Willebrand factor (vWF) were detected in blood samples. The inferior vena cava (IVC) was ligated to establish the DVT model. Rat IL-18 overexpression and inhibition vectors were constructed. The expression levels of IL-18 and related markers in the venous wall were compared between the model group and the control group using reverse transcription-quantitative polymerase chain reaction and western blot analyses. Following the culture of human umbilical vein endothelial cells (HUVECs), IL-18 was added to the cells, following which the growth of the HUVECs, and changes in vWF and other endothelial functional markers were analyzed. The IVC model demonstrated complete thrombosis at $8 \mathrm{~h}$ and stable thrombosis at $24 \mathrm{~h}$. At $24 \mathrm{~h}$ following model establishment, the expression levels of IL-18, NF- $\mathrm{BB}$ and vWF were high in the blood samples with the occurrence and development of thrombosis $(\mathrm{P}<0.05)$. The weight, length and weight/length ratio of thrombi in each model group showed significant differences from those in the control group $(\mathrm{P}<0.05)$ with the overexpression of IL-18, and the expression levels of $\mathrm{NF}-\kappa \mathrm{B}$ and $\mathrm{vWF}$ in venous tissues were altered with abnormal expression levels of IL-18. IL-18 damaged HUVECs and significantly increased viability in early-stage apoptosis, promoted the upregulation of vWF and P-selectin, and reduced tissue plasminogen activator. IL-18
\end{abstract}

Correspondence to: Dr Xueling Zhao, Department of Orthopedics, The First Affiliated Hospital of Kunming Medical University, 295 Xichang Road, Wuhua, Kunming, Yunnan 650032, P.R. China E-mail: 359248760@qq.com

Key words: interleukin-18, nuclear factor- $\kappa \mathrm{B}$, von Willebrand factor, deep venous thrombosis, human umbilical vein endothelial cells and the related markers were closely associated with the occurrence and development of DVT.

\section{Introduction}

Deep venous thrombosis (DVT) is a common traumatic and postoperative complication in patients undergoing orthopedic surgery. Several studies have revealed that DVT is closely associated with the inflammatory reaction. The inflammatory factors can damage the venous wall, causing thrombosis (1). This process involves a vicious cycle, which promotes the mutual effects between the inflammatory response and DVT (2).

Interleukin (IL)-18 is a type of proinflammatory cytokine belonging to the interleukin family, and is detectable in the majority of mammalian cells, including vascular endothelial cells. IL-18 has a multi-directional biological functional activity, and is extensively involved in the regulatory processes of inflammatory and immune reactions. Few studies exist on the correlation between IL-18 and DVT, however, studies on the correlation of IL-18 with inflammatory reactions in the body, cell function regulation and cardiovascular system diseases have suggested that it may be one of the important factors involved in causing thrombosis. It has been revealed (3) that IL-18 can activate nuclear factor- $\kappa \mathrm{B}(\mathrm{NF}-\kappa \mathrm{B})$ and mediate human cerebral microvascular endothelial cell (HCMEC) damage, inducing the dysfunction and apoptosis of cells. $\mathrm{NF}-\kappa \mathrm{B}$ is associated with the expression of tissue factor (TF), and the transcriptional regulatory effects of $\mathrm{NF}-\kappa \mathrm{B}$ and $\mathrm{TF}$ are key in the pathogenesis of DVT (4), with NF- $\kappa \mathrm{B}$ inhibitor used in the prevention and treatment of DVT. In summary, IL-18 and $\mathrm{NF}-\kappa \mathrm{B}$ are closely associated with the functional changes of endothelial cells, and there exists a type of intrinsic association between them, promoting the incidence of DVT.

Therefore, the present study investigated the effect of the expression of IL-18 and related markers on DVT to examine the correlation between IL-18 and DVT.

\section{Materials and methods}

Ethical statement. SPF female Sprague-Dawley (SD) rats aged 8-10 weeks and weighing $180 \pm 20 \mathrm{~g}$ were raised in the SPF Animal Experiment Building, Experimental Animal Center, 
Kunming Medical University (Kunming, China). Rats were housed at room temperature, 50-60\% humidity, $<14 \mathrm{mg} / \mathrm{m}^{3}$ under a $12 \mathrm{~h}$ light/dark cycle. Food and water was provided ad libitum. All animal experiments were performed following approval from the Animal Experiment and Ethics Committee of Kunming Medical University.

Establishment of the rat inferior vena cava (IVC) thrombosis model. The SD rats were randomized into three groups. In the DVT model group $(n=40)$, the IVC thrombosis model was established in rats using the flow restriction method (5) (Fig. 1). In the Sham group $(n=40)$, the IVC was exposed and then sutured, without any invasive treatment. In the control group $(n=40)$, no invasive procedure was performed on the rats. At 2 , 8,24 and $72 \mathrm{~h}, 10$ rats were randomly selected from each group for observation of IVC thrombosis at the preset time-points. Subsequently, 5-8 ml blood was collected using sodium citrate anticoagulant vacutainer (cat. no. 363095; BD Biosciences, Franklin Lakes, NJ, USA), and was centrifuged at $760 \mathrm{x}$ g for $10 \mathrm{~min}$ at $4^{\circ} \mathrm{C}$, followed by isolation of plasma and preservation at $-80^{\circ} \mathrm{C}$. The expression levels of IL-18 and NF- $\kappa$ B in the plasma samples of each group were detected using the ELISA method according to the ELISA kit manufacturer's protocol (IL-18: cat. no. CSB-E04610r; NF-кB: cat. no. CSB-E13148r; Cusabio Biotech Co., Ltd., Wuhan, China).

Construction of overexpression and suppression vectors of the rat IL-18 gene. Construction of the overexpression vector was performed as follows: The complete CDS sequence of the rat IL-18 gene was obtained from GenBank (https://www.ncbi. nlm.nih.gov/genbank/). The primer sequences were designed using BLAST (https://blast.ncbi.nlm.nih.gov/Blast.cgi) and Primer 5.0 (Premier Biosoft International, Palo Alto, CA, USA) software: IL-18 (585 bp), forward, 5'-CGGAATTCA TGGCTGCCATGTCAGAA-3' and reverse, 5'-CGGGATCCC TAACTTTGATGTAAGTT-3'. The details of PCR amplification are as follows, mixed: 30.5 liters double distilled water, 2 liters upstream primers, 2 liters downstream primers, 2 liters cDNA, 4 liters dNTP, 4 liters $\mathrm{MgCl}_{2}$, 5 liters 10X EXTaq Buffer $\left(\mathrm{Mg}^{2+}\right.$ free), 0.5 liter EXTaq; total 50 liters. The thermocycling procedure comprised: $94^{\circ} \mathrm{C}$ for $3 \mathrm{~min} ; 94^{\circ} \mathrm{C}$ for $30 \mathrm{sec} ; 52^{\circ} \mathrm{C}$ for $30 \mathrm{sec} ; 72^{\circ} \mathrm{C}$ for $1 \mathrm{~min} ; 94^{\circ} \mathrm{C}$ for $30 \mathrm{sec}, 30$ cycles; $72^{\circ} \mathrm{C}$ for $10 \mathrm{~min}$ and hold at $4^{\circ} \mathrm{C}$; annealing temperature $56^{\circ} \mathrm{C}$.

The gene fragment was amplified by polymerase chain reaction (PCR). The target gene fragment and plasmid vector were constructed according to the manufacturer's protocol of the pCDHcDNA cloning and expression lentivectors, pCDH-MCS-T2A-copGFP-MSCV (cat. no. CD523A-1; System Biosciences, Inc., Mountain View, CA, USA).

Construction of the suppression vector first involved amplification of the rat IL-18 gene retrovirus oligo fragments: Two 22-base candidate small interfering (si)RNA target sequences were designed using Oligoengine 2.0 online software (http://bioinfo. clontech.com/rnaidesigner/frontpage.jsp): 5'-TGCTGTTGACAG TGAGCGCAGGTCTCCACTGCTGCCCTTGTAGTGAAG CCACAGATGTACAAGGGCAGCAGTGGAGACCTGTGC CTACTGCCTCGGA-3' and 5'-TGCTGTTGACAGTGA GCGCCCAGCTGGTGTCCTAGCAGATTAGTGAAGCCA CAGATGTAATCTGCTAGGACACCAGCTGGGTGCCTA CTGCCTCGGA-3'. For PCR, the oligo used microRNA
(miR)30, forward (XhoI), 5'-CAGAAGGCTCGAGAAGGTATA TTGCTGTTGACAGTGAGCG-3' and reverse (EcoRI), 5'-CTA AAGTAGCCCCTTGAATTCCGAGGCAGTAGGCA-3'. These oligo fragments were amplified, and the target fragment and plasmid vector were constructed using the expression arrest microRNA-adapted retroviral vector (LMP microRNA-adapted vector), according to the manufacturer's protocol (cat. no. EAV4071; Thermo Fisher Scientific, Inc., Waltham, MA, USA).

Acquisition of plasmid virus with IL-18 overexpression and inhibition, and efficiency determination. In the present study, 293T cells (The Cell Bank of Type Culture Collection of Chinese Academy of Sciences, Shanghai, China) were used as the host cells for packaging viruses, and rat fibroblasts were used as the infected cells. For packaging and infection of the viral vectors, the pCDH-GFP lentivirus (12 g) was packaged with the pCL-ECO plasmid ( $8 \mathrm{~g}$ ) and was transfected into the overexpression plasmid IL-18-pCDH-GFP using HEPES and the Calcium Phosphate Cell Transfection kit (Beyotime Institute of Biotechnology, Jiangsu, China) according to the manufacturer's protocols Normal cells and cells transfected with null vectors were used as controls. The MSCV-LMP retrovirus (12.5 g) had two packaging plasmids: pAPAX (7.5 g) and pMD2.G (5 g). This was transfected into IL-18-LMP short hairpin (sh)RNAmir1 and plasmid 2, whereas transfection with null vectors were used as controls.

The target plasmid and packaging plasmid were added to $1.5 \mathrm{mlEP}$ tubes in sequence and centrifuged at $300 \mathrm{x} \mathrm{g}$ for $10 \mathrm{sec}$ at room temperature. Subsequently, $60 \mu 12 \mathrm{M}$ calcium chloride was added to each tube with $420 \mu \mathrm{l}$ sterile distilled water, followed by vortex mixing and centrifugation (solution A). Subsequently, new $1.5 \mathrm{ml}$ EP tubes were selected and $500 \mu \mathrm{l}$ HEPES buffer was added to each (solution B). On a vortex, the solution (A) was slowly dripped into solution B ( 25-28 drops), and then stood at room temperature for $30 \mathrm{~min}$. This mixture was then slowly dripped into the $293 \mathrm{~T}$ cell culture flask and stood for 6-8 h, followed by replacement of the medium and further culture. The transfection time was from $2 \mathrm{~h}$ following the application of the plasmid mixture. At $48 \mathrm{~h}$, medium containing the virus was collected and filtered using a filtration membrane $(0.45-\mu \mathrm{m})$. Subsequently, $7 \mathrm{ml}$ fresh medium was poured into a culture dish, from which the rat fibroblasts medium prepared on the 2 nd day of transfection was removed and added to medium containing the virus, with $2 \mu \mathrm{l}$ of Polybrene added to promote infection. Subsequently, virus secreted for the second time was collected and was used to infect the target cells again, to which polybrene was added. The infection efficiency was observed when the total infection time was $48 \mathrm{~h}$.

Determination of IL-18 overexpression and inhibition efficiency. RNA was extracted from the infected cells, and was synthesized into cDNA according to the RevertAid First Strand cDNA synthesis kit (MBI Fermentas; Thermo Fisher Scientific, Inc., Pittsburgh, PA, USA) protocol. Subsequently, the relative expression of IL-18 was determined using reverse transcription-quantitative (RT-q)PCR analysis according to the manufacturer's protocol of Maxima ${ }^{\circledR} \mathrm{SYBR}-\mathrm{Green} / \mathrm{ROX}$ qPCR Master mix (2X) (MBI Fermentas; Thermo Fisher Scientific, Inc.). The ABI PRISM ${ }^{\circledR} 7300$ HT system (Applied Biosystems; Thermo Fisher Scientific, Inc.) was used for detection of the 


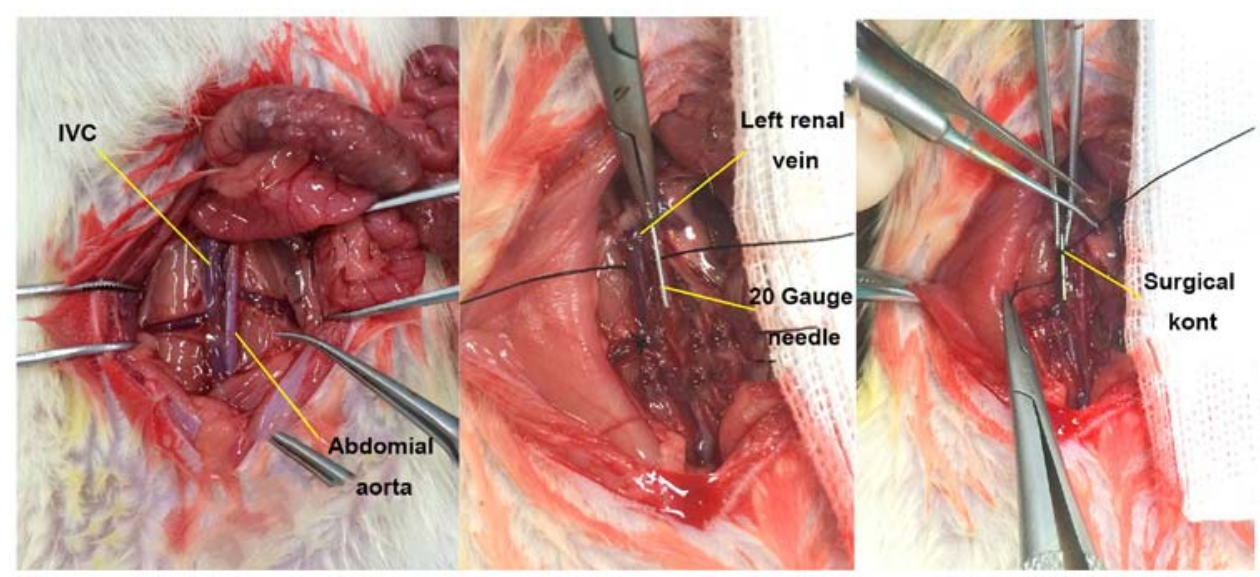

Figure 1. Anatomy and modeling of IVC in rats. The IVC was disserted and exposed, and a 20 -gauge $(\mathrm{d}=0.91 \mathrm{~mm})$ syringe needle was placed in parallel. The IVC and the needle were ligated with 7-0 polypropylene sutures at $\sim 1 \mathrm{~mm}$ below the left renal vein, and then the needle was removed for partial flow restriction of the blood. IVC, inferior vena cava.

relative expression of IL-18 via for RT-qPCR analysis. The thermocycling conditions constituted: Initial denaturation at $95^{\circ} \mathrm{C}$ for $10 \mathrm{~min}$ ( 1 cycle), followed by denaturation at $95^{\circ} \mathrm{C}$ for $15 \mathrm{sec}$, and annealing and extension at $60^{\circ} \mathrm{C}$ for $60 \mathrm{sec}(40$ cycles). The primer sequences were obtained using the $2^{-\Delta \Delta C q}$ method (6) (ABI DataAssist ${ }^{\mathrm{TM}}$ v3.0 software (Thermo Fisher Scientific, Inc.) and were as follows: Rat IL-18 (82 bp), forward, 5'-TCT GTAGCTCCATGCTTTCCG-3' and reverse, 5'-GATCCT GGAGGTTGCAGAAGA-3'; Rat GAPDH (146 bp), forward, 5'-ACGGCAAGTTCAACGGCACAG-3' and reverse, 5'-GAC GCCAGTAGACTCCACGACA-3'.

Acquisition of virus. At 48 and $72 \mathrm{~h}$, the virus stock solution containing the IL-18-pCDH-GFP overexpression plasmid and IL-18-LMP shRNAmir1 inhibition plasmid was collected, centrifuged with an ultrafiltration tube at $14,000 \mathrm{x}$ g for $30 \mathrm{~min}$ at low-temperature, followed by centrifugation with a high-speed refrigerated centrifuge at $85,000 \mathrm{x} g$ for $2 \mathrm{~h}$. The precipitation was retained, and 50-100 $\mu$ l PBS was added into each tube, and then placed on a horizontal shaker overnight at $4^{\circ} \mathrm{C}$. The virus concentrate was then collected and preserved at $-80^{\circ} \mathrm{C}$.

Treatment and modeling of rats with $I L-18$ gene overexpression and inhibition. The SD rats were randomly assigned into four groups: In the overexpression group $(n=10)$, rats were administered with an intravenous tail injection of IL-18-pCDH-GFP overexpression virus, (300 $\mu \mathrm{l} / \mathrm{rat})$. In the inhibition group $(n=10)$, rats were administered with IL-18 LMP shRNAmir1 inhibition virus (300 $\mu \mathrm{l} / \mathrm{rat})$. Rats in the control group $(n=5)$ were injected with sterile saline (300 $\mu \mathrm{l} / \mathrm{rat})$. Rats in the normal group $(\mathrm{n}=5)$ received no treatment. After $24 \mathrm{~h}$, the IVC thrombus model was prepared using the flow restriction method (5) in the overexpression, inhibition and control groups. At $24 \mathrm{~h}$ post-model establishment, the rats were anatomized, and the IVC and embolus below the ligation suture were collected for measurement of the weight and length. In the normal group, the IVC (length of $\sim 1.0-1.5 \mathrm{~cm}$ ) was collected under the left renal vein inlet.

The total protein was extracted from the vein wall using radioimmunoprecipitation assay buffer (Beyotime Institute of Biotechnology) and centrifugation at 14,000 x g for $5 \mathrm{~min}$ at $4^{\circ} \mathrm{C}$. Total protein was quantified via a bicinchoninc acid (BCA) protein assay; $30 \mu \mathrm{g}$ proteins were separated via $10 \%$ SDS-PAGE, which were then transferred to nitrocellulose membranes. For blocking, 5\% milk was applied for $2.5 \mathrm{~h}$ at $20-25^{\circ} \mathrm{C}$. The expression levels of IL-18 (1:1,000; cat. no. sc-7954; Santa Cruz Biotechnology, Inc., Dallas, TX, USA) and NF- $\mathrm{B}$ (1:1,000; cat. no. p65-10745-1-AP; ProteinTech Group, Inc., Chicago, IL, USA) were analyzed using western blot analysis. The membrane was incubated with the aforementioned primary antibodies overnight at $4^{\circ} \mathrm{C}$. Subsequently, the membranes were incubated with goat anti-rabbit IgG horseradish peroxidase (HRP; $\mathrm{H}+\mathrm{L})$ secondary antibody $(1: 10,000$; cat. no. 31460; Thermo Fisher Scientific, Inc.) for $2 \mathrm{~h}$ at $4^{\circ} \mathrm{C}$. The protein was developed using ECL Plus according to the manufacturer's protocol of the ECL kit (Beyotime Institute of Biotechnology). Images of the staining were captured using a GEL imaging system (GelDoc XR System; Bio-Rad Laboratories, Inc., Hercules, CA, USA), and the band results were semi-quantitatively analyzed using Quantity One 4.6 software (Bio-Rad Laboratories, Inc.) to obtain the corresponding optical density values. The ratio was attained using the following formula: Ratio=target $/ \beta$-actin.

RNA extracted from the vein wall and synthesized into cDNA as aforementioned via RT, and the target gene expression was analyzed using qPCR analysis. A reaction master mix was prepared by adding the following components for each $25 \mu \mathrm{l}$ reaction to a tube at room temperature: $12.5 \mu \mathrm{l}$ Maxima ${ }^{\circledR}$ SYBR-Green/ROX qPCR Master Mix (2X), $0.3 \mu 1$ PCR forward primer $(10 \mu \mathrm{M}), 0.3 \mu \mathrm{l}$ PCR reverse primer $(10 \mu \mathrm{M}), 500 \mathrm{ng}$ template DNA and water, nuclease-free to $25 \mu \mathrm{l}$. The primer sequences were analyzed using the $2^{-\Delta \Delta \mathrm{Cq}}$ method (6): IL-18 (240 bp), forward, 5'-AATCAGACCACT TTGGCAGAC-3' and reverse, 5'-TTTTACAGGAGAGGG TAGACATCC-3'; NF-кB (297 bp), forward, 5'-TCCAACACA GGCATCACCCA-3' and reverse, 5'-CTTCACATCTCCCGT AACCGC-3'; GAPDH (146 bp), forward, 5'-ACGGCAAGT TCAACGGCACAG-3' and reverse, 5'-GACGCCAGTAGA CTCCACGACA-3'. The thermocycling conditions constituted: Initial denaturation at $95^{\circ} \mathrm{C}$ for $10 \mathrm{~min}$ (1 cycle); denaturation at $95^{\circ} \mathrm{C}$ for $15 \mathrm{sec}$; annealing at $60^{\circ} \mathrm{C}$ for $30 \mathrm{sec}$ and extension at $72^{\circ} \mathrm{C}$ for $30 \mathrm{sec}$ (40 cycles). 
Effect of IL-18 activated NF- $\kappa$ B on human umbilical vein endothelial cells (HUVECs). Fresh normal HUVECs (cat. no. 1-0025; CHI Scientific, Inc., Jiangsu, China) were collected and cultured at $37^{\circ} \mathrm{C}$, in a $5 \% \mathrm{CO}_{2}$ saturated humidity incubator for 2-3 h. The original culture medium was discarded, and the cells were digested using $0.25 \%$ EDTA trypsin at $37^{\circ} \mathrm{C}$ for $2 \mathrm{~min}$ for contraction. The cells were the inoculated in 2-4 culture flasks for preparing stationary culture. The medium was initially displaced at $72 \mathrm{~h}$, and was subsequently displaced every 1-2 days according to the cell growth and experimental arrangement.

Measurements associated with the IL-18-activated NF- $\kappa B$ signaling pathway. The HUVECs were divided into three groups according to different pretreatment methods: Group A (control), comprised cells routinely cultured for $24 \mathrm{~h}$. Group B (IL-18) comprised cells pretreated with IL-18 $(50 \mathrm{ng} / \mathrm{ml}$; recombinant human IL-18, cat. no. CYT-269; Prospec-Tany Technogene Ltd., Rehovot, Israel) for $24 \mathrm{~h}$. Group C (IL-18+QNZ) comprised cells were pretreated with IL-18 $50 \mathrm{ng} / \mathrm{ml}$ for $12 \mathrm{~h}$, followed by addition of $50 \mu \mathrm{M} / \mathrm{ml} \mathrm{NF- \kappa B}$ activation inhibitor QNZ (EVP4593, cat. no. s4902; Selleck Chemicals, Houston, TX, USA) and further culture until $24 \mathrm{~h}$. Subsequently, nucleoprotein and plasma protein were isolated and extracted from the HUVECs according to the manufacturer's protocol of the Nuclear and Cytoplasmic Protein Extraction kit (cat. no. P0028; Beyotime Institute of Biotechnology). The expression levels of NF- $\mathrm{BB}-\mathrm{p} 65$ (p65 polyclonal antibody, cat. no. 10745-1-AP) and inhibitor of NF-B (I $\kappa$ B $\alpha$ polyclonal antibody, cat. no 10268-1-AP) (both from ProteinTech Group, Inc.) in the cytoplasm and nucleus were examined, respectively, using western blot and immunofluorescence staining methods. The results were observed under a fluorescence microscope (Nikon Eclipse 90i; Nikon Corporation, Tokyo, Japan)

Effect of IL-18-activated NF- $\kappa B$ on cell state and function. For the detection of apoptosis, pretreated cells were subjected to mitochondrial membrane potential detection using a mitochondrial membrane potential assay kit with $\mathrm{JC}-1$ according to the manufacturer's protocol (cat. no. C2006; Beyotime Institute of Biotechnology), in which a fluorescence microscope (Nikon Eclipse 90i) was used for observation. The cells in each group were then analyzed using Annexin V-FITC/PI flow cytometry (CyFlow ${ }^{\circledR}$ Space; SysmexPartec GmbH, Görlitz, Germany) according to the manufacturer's protocol of the Annexin V-FITC Apoptosis Detection kit (cat. no. C1062; Beyotime Institute of Biotechnology).

Detection of endothelial cell-related markers. The endothelial cells were divided into three groups and were pretreated as described previously. Total protein was isolated from $5-10 \times 10^{5}$ treated cells using SDS Lysis Buffer (Beyotime Institute of Biotechnology), and incubated on ice for $30 \mathrm{~min}$. Cells were centrifuged at $14,000 \mathrm{x}$ g for $5 \mathrm{~min}$ at $4^{\circ} \mathrm{C}$. Total protein was quantified by a BCA protein assay; $30 \mu \mathrm{g}$ proteins were separated via $10 \%$ SDS-PAGE and then transferred onto nitrocellulose membranes, which were blocked with $5 \%$ milk for $2.5 \mathrm{~h}$ at $20-25^{\circ} \mathrm{C}$. The membranes were incubated with primary antibodies $(1: 1,000)$ against vWF $(\mathrm{C}-12$, cat. no. sc-365712), P-selectin (CTB201, cat. no. sc-8419) and tissue plasminogen activator (t-PA; C-16, cat. no. sc-5239) (all from Santa Cruz Biotechnology, Inc.) overnight at $4^{\circ} \mathrm{C}$. Subsequently, the membranes were then incubated with goat anti-rabbit IgG HRP (H+L) secondary antibodies $(1: 10,000)$ for $2 \mathrm{~h}$ at $4^{\circ} \mathrm{C}$.

For RT-qPCR analysis, total RNA was extracted from the HUVECs of each group and synthesized into cDNA. A reaction master mix was prepared by adding the following components for each $25 \mu \mathrm{l}$ reaction to a tube at room temperature: $12.5 \mu 1$ Maxima ${ }^{\circledR}$ SYBR-Green/ROX qPCR Master Mix (2X), $0.3 \mu \mathrm{l}$ PCR forward primer $(10 \mu \mathrm{M}), 0.3 \mu \mathrm{l}$ PCR reverse primer $(10 \mu \mathrm{M}), 500 \mathrm{ng}$ template DNA and water, nuclease-free to $25 \mu \mathrm{l}$. The themocycling conditions constituted: Initial denaturation at $95^{\circ} \mathrm{C}$ for $10 \mathrm{~min}$ (1 cycle); denaturation at $95^{\circ} \mathrm{C}$ for $15 \mathrm{sec}$; annealing/extension for $60^{\circ} \mathrm{C}$ for $60 \mathrm{sec}$ (40 cycles).

The primers included were as follows: Human vWF, forward 5'-TCCTCCTACTCTGCCCCCC-3' and reverse, 5'-TCCATC CGCTGAATCACCTC-3'; human P-selectin, forward 5'-CCG TGCGTAATTACTCCCCC-3' and reverse, 5'-AGGCTTTCT CGGCTTCATCTG-3'; human t-PA, forward, 5'-CCCAGA TCGAGACTCAAAGCC-3' and revesre, 5'-TGACCCATT CCCAAAGTAGCAG-3'; human $\beta$-actin, forward, 5'-ACG GCAAGTTCAACGGCACAG-3' and reverse, 5'-GACGCC AGTAGACTCCACGACA-3'. The $2^{-\Delta \Delta C q}$ method (6) was used for experimental analysis.

Statistical analysis. Statistical analyses were performed using SPSS 19.0 software (IBM SPSS, Armonk, NY, USA). Measurement data are expressed as the mean \pm standard deviation. Intergroup comparisons were performed using one-way analysis of variance (F test) and multiple comparisons were performed using the LSD method. A 95\% confidence interval was adopted, and $\mathrm{P}<0.05$ was considered to indicate a statistically significant difference.

\section{Results}

Rat modeling. In the DVT model group, thrombosis was clearly visible following model establishment (Fig. 2). During the experiment, the average diameter of the rat IVC was $2.898 \pm 0.279 \mathrm{~mm}$. Considering the diameter of a $20-\mathrm{G}$ needle as $0.91 \mathrm{~mm}$, the average residual cross-sectional area of the IVC lumen following modeling using the flow restriction method was $9.87 \pm 1.67 \%$. A favorable thrombosis rate was obtained if the residual cross-sectional area of the lumen was controlled at $\sim 10 \%$ in the IVC thrombosis model using the flow restriction method. This was consistent with the results reported by Brill et al (5).

Blood ELISA results. In the plasma of the DVT model group, the protein concentrations of IL-18 (Table I and Fig. 3) and NF- $\mathrm{B}$ (Table II and Fig. 4) were increased at all time-points, and were significantly higher than those in the other two groups.

Detection of IL-18 gene overexpression and inhibition efficiencies. The results of RT-qPCR analysis (Table III) revealed the expression of IL-18 the gene in the overexpression and inhibition groups and showed significant differences compared with that in the control group. The gene expression 
Table I. Protein concentrations of IL-18.

\begin{tabular}{|c|c|c|c|c|}
\hline \multirow[b]{2}{*}{ Time-point (h) } & \multicolumn{3}{|c|}{ Concentration (ng/ml) } & \multirow[b]{2}{*}{$\mathrm{n}$} \\
\hline & Normal & Sham & Model & \\
\hline 2 & $122.283 \pm 43.703$ & $137.986 \pm 32.865$ & $140.607 \pm 35.471$ & 30 \\
\hline 8 & $135.133 \pm 46.451$ & $159.335 \pm 30.756$ & $185.760 \pm 64.050^{\mathrm{a}}$ & 30 \\
\hline 24 & $139.516 \pm 62.830$ & $212.496 \pm 48.515^{\mathrm{a}}$ & $285.153 \pm 97.398^{b}$ & 30 \\
\hline 72 & $121.682 \pm 37.450$ & $185.883 \pm 58.455^{\mathrm{a}}$ & $255.160 \pm 83.531^{\mathrm{b}}$ & 29 \\
\hline Total & $129.653 \pm 47.288$ & $173.925 \pm 51.021$ & $215.683 \pm 91.342$ & 119 \\
\hline
\end{tabular}

Data are presented as the mean \pm standard deviation. In the sham group, IL-18 was significantly increased at 24 and $72 \mathrm{~h}$, compared with the normal group. In the model group, IL-18 was significantly higher than in the normal group at $8 \mathrm{~h}$, and was increased further at $24 \mathrm{~h}$. ${ }^{\mathrm{a}} \mathrm{P}<0.05$ and ${ }^{\mathrm{b}} \mathrm{P}<0.005$ compared with the normal group. IL-18, interleukin-18.

Table II. Protein concentrations of NF- $\mathrm{NB}$.

\begin{tabular}{|c|c|c|c|c|}
\hline \multirow[b]{2}{*}{ Time-point (h) } & \multicolumn{3}{|c|}{ Concentration (ng/ml) } & \multirow[b]{2}{*}{$\mathrm{n}$} \\
\hline & Normal & Sham & Model & \\
\hline 2 & $2,140.567 \pm 1,197.236$ & $2,072.758 \pm 1,396.933$ & $2,230.484 \pm 1,025.352$ & 30 \\
\hline 8 & $2,282.417 \pm 1,078.633$ & $2,412.840 \pm 1,010.100$ & $2,762.880 \pm 1,250.555$ & 30 \\
\hline 24 & $2,436.232 \pm 1,181.866$ & $2,889.602 \pm 1,038.773$ & $3,897.117 \pm 998.730^{\mathrm{a}}$ & 30 \\
\hline 72 & $2,235.919 \pm 1,343.126$ & $2,417.126 \pm 794.822$ & $3,418.390 \pm 1,196.602^{\mathrm{a}}$ & 29 \\
\hline Total & $2,273.784 \pm 1,161.730$ & $2,448.081 \pm 1,080.393$ & $3,068.470 \pm 1,255.448$ & 119 \\
\hline
\end{tabular}

Data are presented as the mean \pm standard deviation. In the model group, NF- $\mathrm{KB}$ was significantly increased at 24 and $72 \mathrm{~h}$, compared with that in the normal group. No significant differences were observed between the sham group and normal group at any time-point. ${ }^{\mathrm{a}} \mathrm{P}<0.05$ compared with the normal group. NF- $\kappa \mathrm{B}$, nuclear factor- $\kappa \mathrm{B}$.

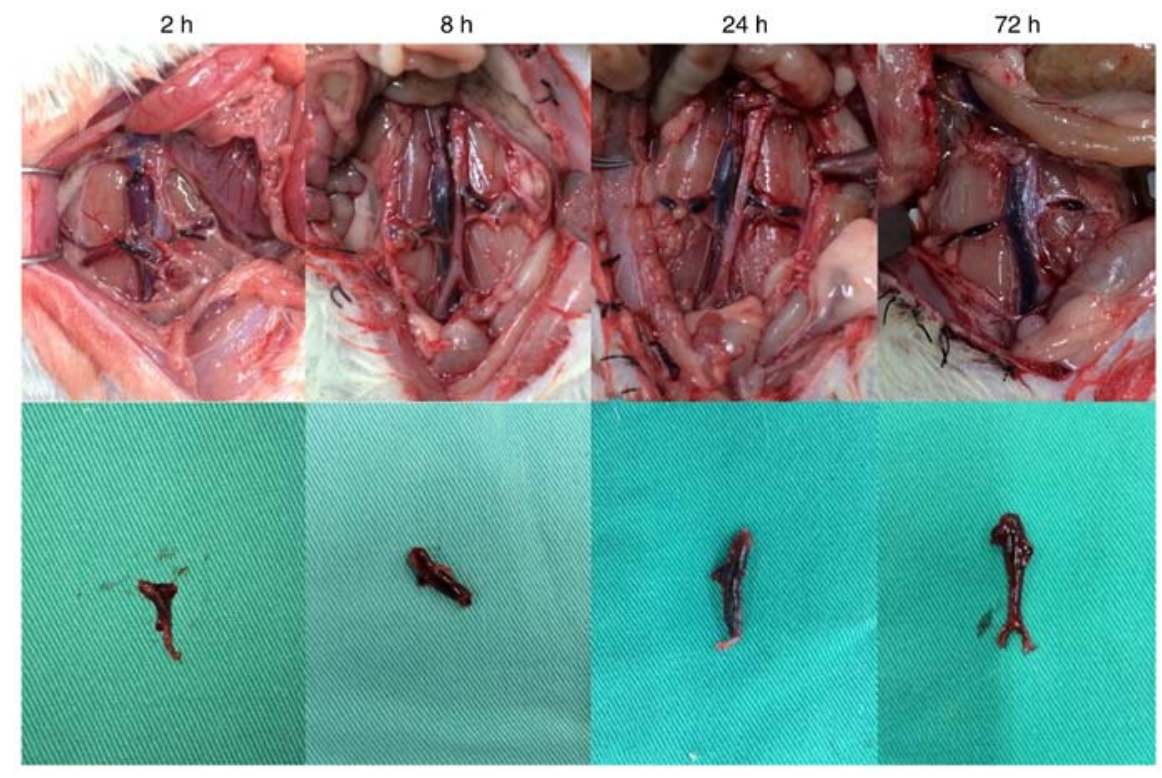

Figure 2. Thrombosis in the deep venous thrombosis model group. At $2 \mathrm{~h}$, the whole segment of the vein was dark red, with the coagulum in the lumen moving when the lumen wall was compressed. At $8 \mathrm{~h}$, the vein had darkened and the coagulum was harder. At $24 \mathrm{~h}$, the vein appeared black red, the thrombosis inside the vein remained tough, the vein demonstrated decreased mobility and inflammatory manifestation. At $72 \mathrm{~h}$, the vein and embolus were stiff and dark black.

of IL-18 was significantly increased in the overexpression group (IL-18-pCDH-GFP) and significantly decreased in the inhibition group. It was downregulated more in the inhibition 1 group (IL-18-LMP shRNAmir1), as shown in Fig. 5. 


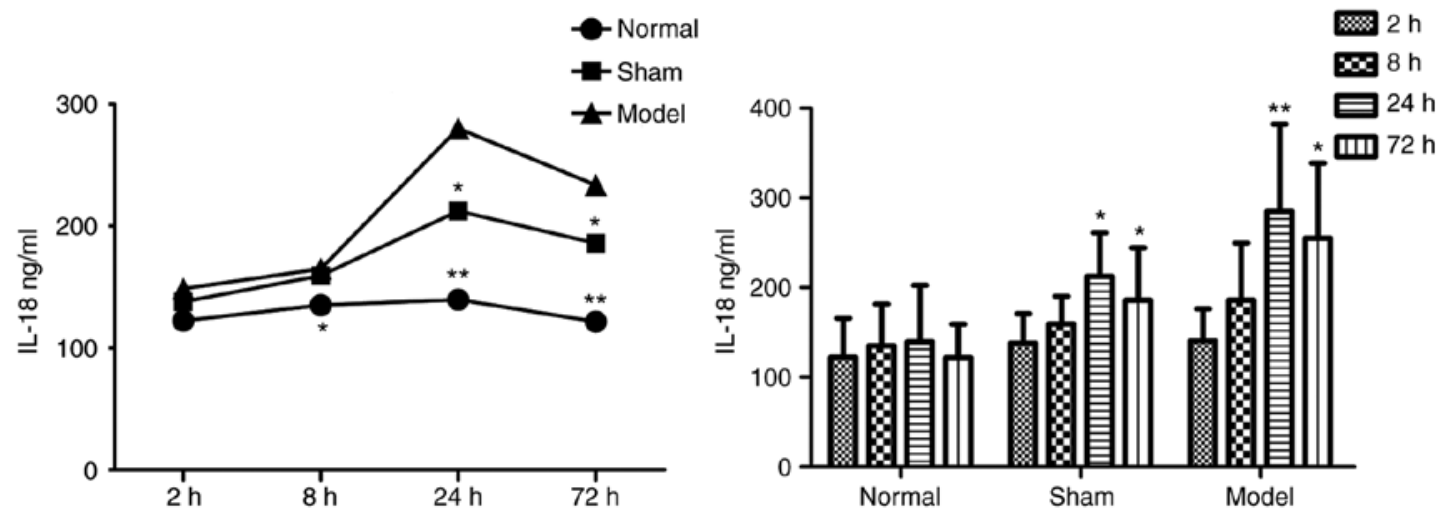

Figure 3. Intragroup comparison of IL-18 at different time-points. The concentration of IL-18 was significantly increased at $24 \mathrm{~h}$ in the model and sham groups ${ }^{*} \mathrm{P}<0.05$ and ${ }^{* *} \mathrm{P}<0.005$ vs. Normal group. IL-18, interleukin-18.
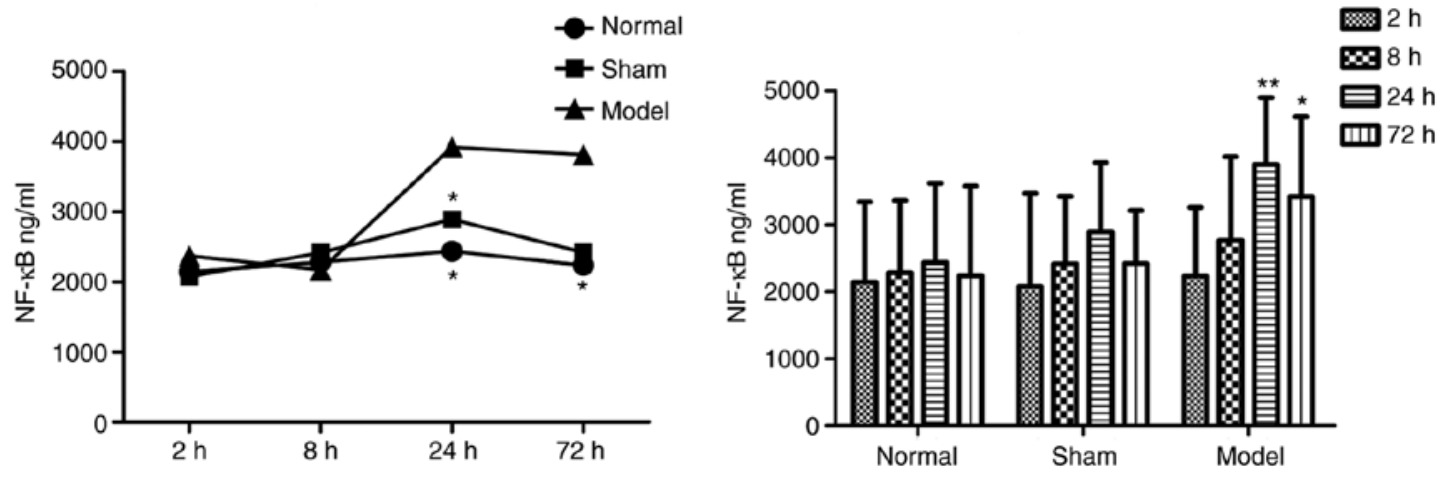

Figure 4. Intragroup comparison of NF- $\mathrm{BB}$ at different time-points. The concentration of NF- $\mathrm{BB}$ was significantly increased at $24 \mathrm{~h}$ in the model and sham

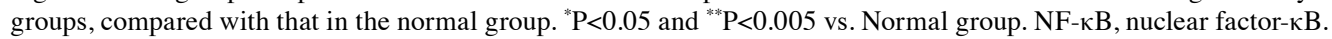

Table III. Expression of interleukin-18.

\begin{tabular}{lc}
\hline Group & $2^{-\Delta \Delta \mathrm{Cq}}($ rat $)$ \\
\hline Control & 1 \\
Null vector & 0.78 \\
Overexpression & 3.04 \\
Control & 1 \\
Null vector & 0.77 \\
Inhibition 1 & 0.25 \\
Inhibition 2 & 0.36
\end{tabular}

This indicated ideal efficiencies of the plasmid virus with overexpression and inhibition of IL-18.

Observation of thrombosis in rats. In each model group, varying degrees of IVC thromboses were visible at $24 \mathrm{~h}$ post-model establishment (Fig. 6). Compared with the control group: i) Thrombus length differed significantly in the overexpression and inhibition groups $(\mathrm{F}=7.965$, $\mathrm{P}=0.002)$. This was significantly higher in the overexpression group compared with the inhibition group $(\mathrm{P}=0.001)$. ii) Thrombus weight differed significantly in the overexpression and inhibition groups $(\mathrm{F}=18.178, \mathrm{P}<0.001)$. This was significantly higher in the overexpression group compared

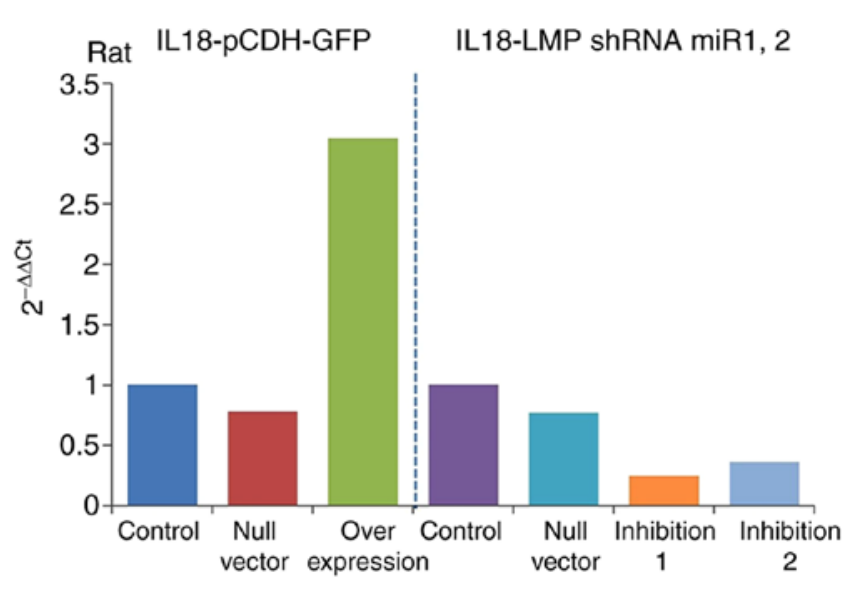

Figure 5. Expression of IL-18. IL-18, interleukin-18; shRNA, short hairpin; mir, microRNA.

with the normal $(\mathrm{P}=0.036)$ and inhibition groups $(\mathrm{P}<0.001)$, and was significantly lower in the inhibition group compared with the normal group $(\mathrm{P}=0.013)$. iii) Weight-length ratio, which indirectly reflects the integrity of the thrombus $(7,8)$ did not differ significantly between the overexpression and the control groups $(\mathrm{P}=0.551)$. However, thrombosis in the inhibition group was significantly weaker, compared with that in the overexpression $(\mathrm{P}=0.001)$ and control groups $(\mathrm{P}=0.019)$ (Table IV and Fig. 7). 
Table IV. Lengths and weights of thrombi.

\begin{tabular}{lccc}
\hline Group & Length $(\mathrm{cm})$ & Weight $(\mathrm{g})$ & Weight/length $(\mathrm{g} / \mathrm{cm})$ \\
\hline Overexpression & $1.45 \pm 0.48^{\mathrm{a}}$ & $0.0769 \pm 0.0264^{\mathrm{a}}$ & $0.0561 \pm 0.0210$ \\
Inhibition & $0.79 \pm 0.21$ & $0.0241 \pm 0.0895^{\mathrm{a}}$ & $0.0304 \pm 0.0084^{\mathrm{a}}$ \\
Control & $1.03 \pm 0.29$ & $0.0529 \pm 0.0193$ & $0.0511 \pm 0.0086$ \\
Total & $1.10 \pm 0.45$ & $0.0510 \pm 0.0306$ & $0.0448 \pm 0.0188$ \\
\hline
\end{tabular}

Data are presented as the mean \pm standard deviation. ${ }^{\text {a }}<0.05$ compared with the normal group.

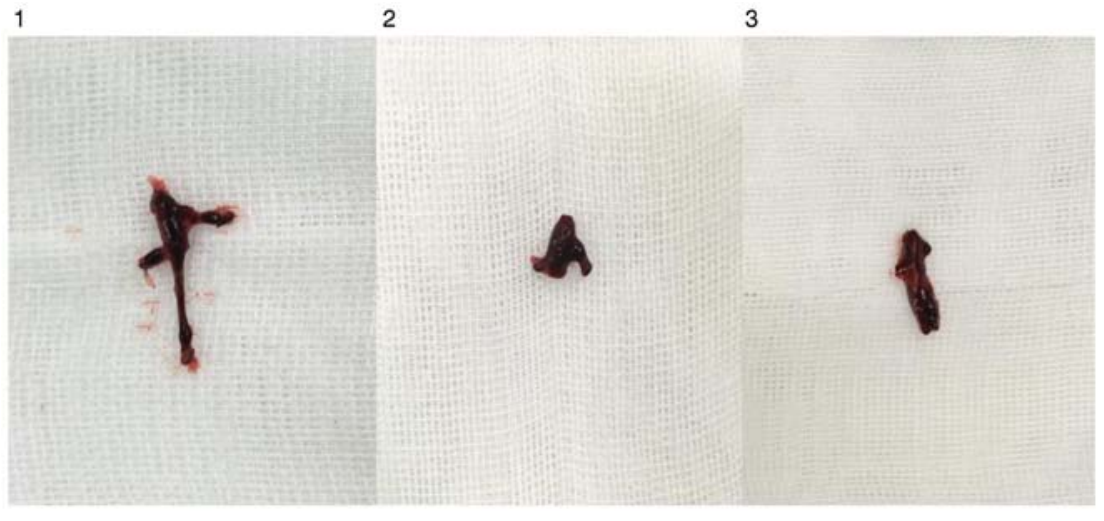

Figure 6. IVC, inferior vena cava thrombosis. 1 , overexpression group; 2 , inhibition group; 3 , control group.
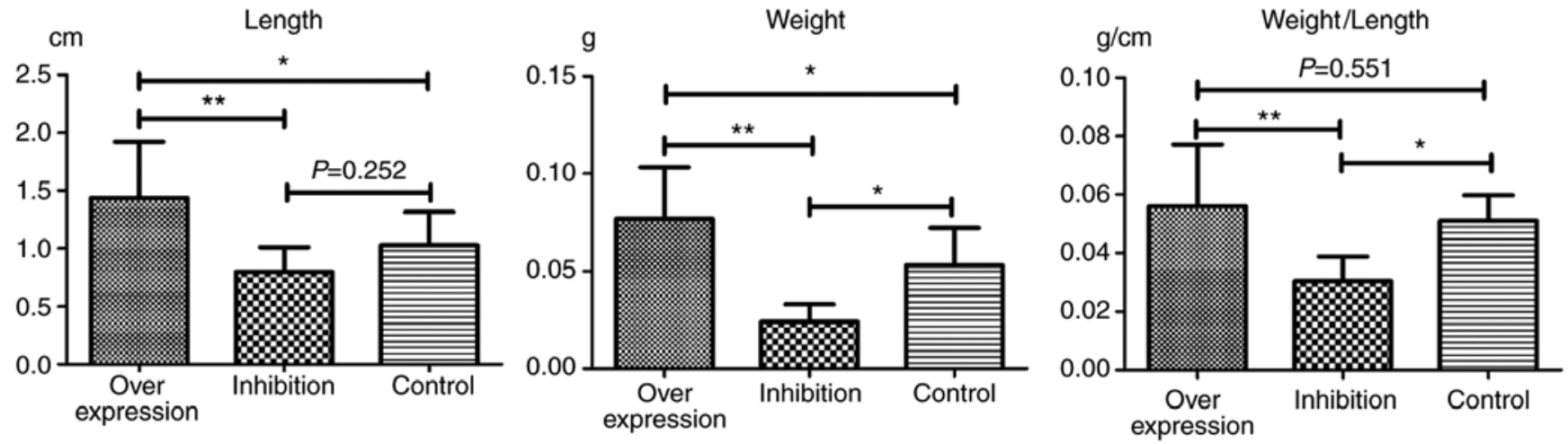

Figure 7. Lengths and weights of thrombi. ${ }^{*} \mathrm{P}<0.05$ and ${ }^{* *} \mathrm{P}<0.005$.
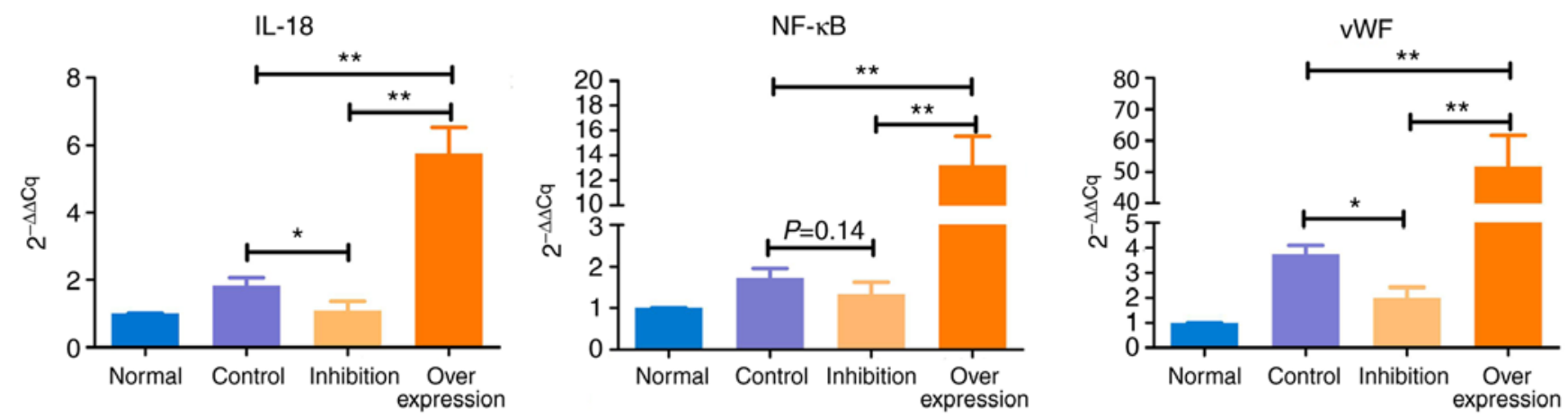

Figure 8. Intergroup comparisons of IL-18, NF- $\mathrm{kB}$ and vWF. Expression of IL-18 was significantly upregulated in the overexpression group ( $\mathrm{P}<0.005)$ and was significantly downregulated in the inhibition group $(\mathrm{P}<0.05)$. Expression levels of NF- $\mathrm{kB}$ and $\mathrm{vWF}$ were significantly increased in the overexpression group $(\mathrm{P}<0.005)$. In the inhibition group, no significant change in the expression of NF- $\kappa \mathrm{B}$ was observed, whereas the expression of $\mathrm{vWF}$ was increased $(\mathrm{P}<0.05)$. IL-18, interleukin-18; NF- $\kappa B$, nuclear factor- $\kappa \mathrm{B}$; vWF, von Willebrand factor. ${ }^{*} \mathrm{P}<0.05$ and ${ }^{* * *} \mathrm{P}<0.005$. 
Table V. Results of reverse transcription-quantitative polymerase chain reaction analysis.

\begin{tabular}{lrlcc}
\hline & & \multicolumn{3}{c}{$2^{-\Delta \Delta C q}$} \\
\cline { 3 - 5 } Group & $\mathrm{n}$ & $\mathrm{IL}-18$ & $\mathrm{NF}-\kappa \mathrm{B}$ & \multicolumn{1}{c}{$\mathrm{vWF}$} \\
\hline Normal & 5 & 1.000 & 1.000 & 1.000 \\
Control & 5 & $1.824^{\mathrm{a}}$ & $1.726^{\mathrm{a}}$ & $3.739^{\mathrm{b}}$ \\
Inhibition & 10 & 1.089 & 1.345 & $2.008^{\mathrm{a}}$ \\
Overexpression & 10 & $5.757^{\mathrm{b}}$ & $13.204^{\mathrm{b}}$ & $51.565^{\mathrm{b}}$
\end{tabular}

${ }^{\mathrm{a}} \mathrm{P}<0.05$ and ${ }^{\mathrm{b}} \mathrm{P}<0.005$, compared with normal group. IL- 18 , interleukin-18; NF- $\mathrm{B}$, nuclear factor- $\mathrm{BB}$; vWF, von Willebrand factor.

Table VI. Relative protein expression levels in different groups (ratio).

\begin{tabular}{lccc}
\hline Group & IL-18 & NF-кB & vWF \\
\hline Normal & 0.686 & 0.693 & 0.767 \\
Control & 1.141 & 0.986 & 1.021 \\
Inhibition & 0.751 & 0.866 & 0.725 \\
Overexpression & 1.667 & 1.285 & 1.589 \\
\hline
\end{tabular}

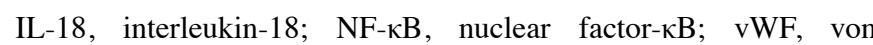
Willebrand factor.

Table VII. Relative expressions of IкB $\alpha$ and p65 (ratio).

\begin{tabular}{lccc}
\hline Group & IкB $\alpha$ & p65-nucleus & p65-cytoplasm \\
\hline A (Control) & 0.743997 & 0.777252 & 0.978306 \\
B (IL-18) & 0.486842 & 1.177360 & 0.578926 \\
C (IL-18+QNZ) & 0.614516 & 0.749936 & 1.153425 \\
\hline
\end{tabular}

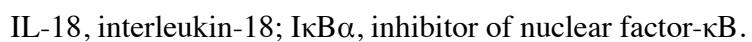

Results of RT-qPCR anaylsis. The expression levels of IL-18, $\mathrm{NF}-\mathrm{\kappa B}$ and $\mathrm{vWF}$ showed similar trends in the various model groups (Table V and Fig. 8): i) Expression levels of IL-18, $\mathrm{NF}-\mathrm{\kappa B}$ and $\mathrm{vWF}$ in the control group were significantly higher, compared with those in the normal group $(\mathrm{P}<0.05)$. ii) Compared with the normal group, expression levels of IL-18 and NF- $\mathrm{KB}$ were marginally increased $(\mathrm{P}>0.05)$, and the expression of vWF was significantly increased $(\mathrm{P}<0.05)$ in the inhibition group. iii) Expression levels of IL-18, NF- $\mathrm{KB}$ and $\mathrm{vWF}$ in the overexpression group were significantly higher, compared with those in the normal rats $(\mathrm{P}<0.005)$.

Results of western blot analysis. In the intravenous tissue, the expression levels of IL-18, NF- $\mathrm{kB}$ and vWF in the normal group were significantly lower compared with those in rats with DVT. In the rats infected with the virus and with IL-18 overexpression and inhibition, the expression of IL-18 in the intravenous tissue was significantly decreased in the inhibition
Table VIII. Relative expression levels of vWF, P-selectin and t-PA (ratio).

\begin{tabular}{lccc}
\hline Group & vWF & P-selectin & t-PA \\
\hline A (Control) & 0.593 & 1.029 & 1.281 \\
B (IL-18) & 1.301 & 1.476 & 0.650 \\
C (IL-18+QNZ) & 0.825 & 1.315 & 0.832 \\
\hline
\end{tabular}

IL-18, interleukin-18; vWF, von Willebrand factor; t-PA, tissue plasminogen activator.

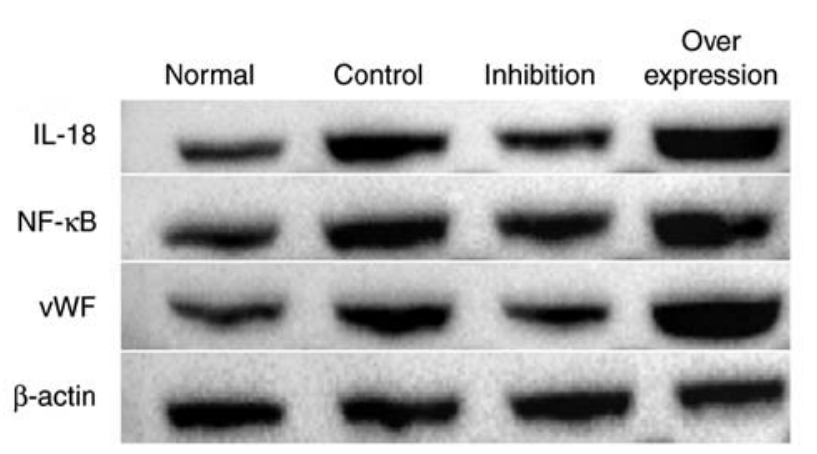

Figure 9. Protein expression of IL-18, NF-kB and vWF in each group. IL-18, interleukin-18; NF- $\mathrm{\kappa B}$, nuclear factor- $\mathrm{\kappa} \mathrm{B}$; vWF, von Willebrand factor.

group, and increased in the overexpression group. The expression levels of NF- $\mathrm{KB}$ and $\mathrm{vWF}$ in each group presented with similar tendencies as with the expression of IL-18 (Figs. 9 and 10, Table VI).

Effect of the IL-18-activated NF- $\kappa B$ signaling pathway on HUVECs. Western blot analysis was performed to detect the expression of IкB $\alpha$ in cells, and the expression of p65 in the cytoplasm and nucleus (Figs. 11 and 12, Table VII). The expression of IкB $\alpha$ was significantly reduced following the application of IL-18, and was increased further following the application of QNZ. The expression of p65 in the nucleus was upregulated in the IL-18 group, compared with that in the control group, and was similar to the normal group following the application of QNZ. The expression of p65 in the cytoplasm was significantly decreased in the IL-18 group, and was increased following administration of QNZ.

Immunofluorescence results. In group A (control), p-p65 was expressed at a low level. In group B, the p65-p50 dimer had migrated to the nucleus following the activation of NF- $\mathrm{\kappa B}$ by IL-18, and the fluorescence signal appeared shiny and bright green in color. In group C, following application of the QNZ inhibitor, the green fluorescence intensity was reduced, and the activation of NF- $\mathrm{kB}$ was suppressed (Fig. 13).

Analysis of cell apoptosis. A mitochondrial membrane potential assay was performed. In group A group, normal cells were in good condition, J-aggregates showed significant red fluorescence, whereas JC-1 monomers showed weak green fluorescence. In group B group, IL-18 showed significantly weakened red fluorescence, whereas bright green fluorescence 

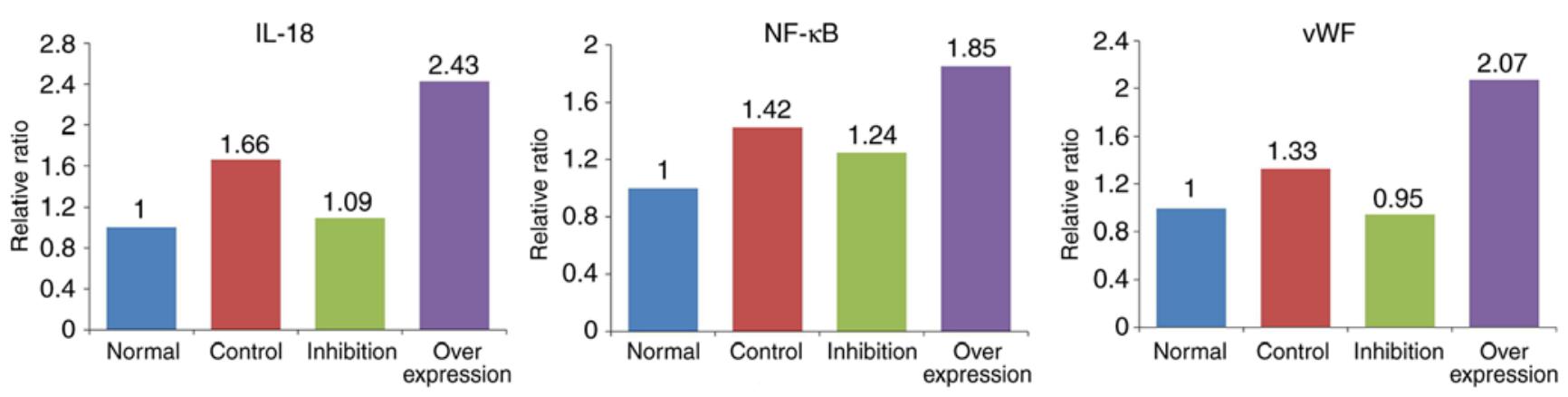

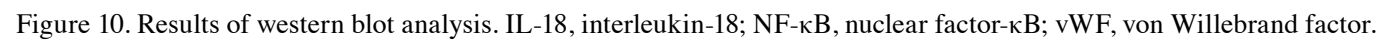

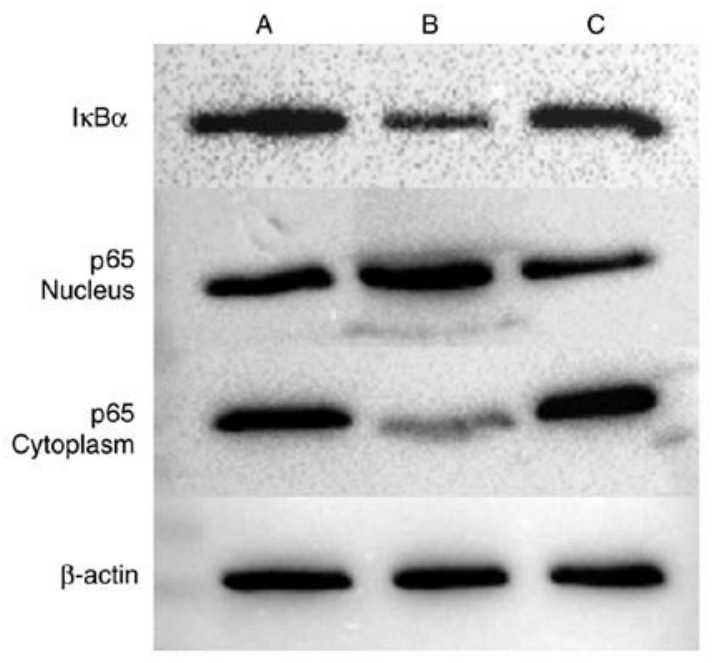

Figure 11. Western blot analysis of IкB $\alpha$ and p65. A, control; B, IL-18 treatment; C, IL-18+QNZ treatment. NF- $\kappa B$, nuclear factor- $\kappa B$; I $\mathrm{KB} \alpha$, inhibitor of NF- $\mathrm{kB}$.

appeared, decreasing the mitochondrial membrane potential. In group C, the application of QNZ suppressed IL-18 from activating $\mathrm{NF}-\kappa \mathrm{B}$, the number of cells with normal mitochondrial membrane potential was significantly increased (red fluorescence) and the apoptotic cells were reduced (green fluorescence) (Fig. 14).

Annexin V-FITC/PI flow cytometry results. In group A, normal viable cells accounted for $98.71 \%$, and the viable apoptotic cells, early apoptotic and necrotic cells accounted for 0.02 and $0.14 \%$, respectively. In group B, normal viable cells accounted for only $68.70 \%$, and the early apoptotic cells accounted for $27.76 \%$, which was significantly higher compared with that in group A group. The number of late apoptotic and necrotic cells was increased compared with that in group A. In group C, normal viable cells accounted for $93.35 \%$, and the number of early apoptotic cells was significantly lower compared with that in the group B, whereas the number of late apoptotic and necrotic cells accounted for $0.43 \%$, which was close to the number in group A (Fig. 15A-C).

Results of western blot analysis of endothelial cell-related markers. Various markers were affected following the activation of NF- $\kappa$ B by IL-18. Compared with the control group, the expression levels of $\mathrm{vWF}$ and P-selectin were significantly
Table IX. Gene expression levels determined using reverse transcription-quantitative polymerase chain reaction analysis.

\begin{tabular}{llcl}
\hline & \multicolumn{3}{c}{$2^{-\Delta \Delta \mathrm{Cq}}$} \\
\cline { 2 - 4 } Group & vWF & P-selectin & t-PA \\
\hline A (Control) & 1.000 & 1.000 & 1.000 \\
B (IL-18) & $3.513^{\mathrm{a}}$ & $1.997^{\mathrm{a}}$ & $0.276^{\mathrm{b}}$ \\
C (IL-18+QNZ) & 1.138 & 1.461 & 0.932
\end{tabular}

${ }^{\mathrm{a}} \mathrm{P}<0.05$ and ${ }^{\mathrm{b}} \mathrm{P}<0.005$, compared with group A. IL-18, interleukin-18; vWF, von Willebrand factor; t-PA, tissue plasminogen activator.

upregulated in the other groups. t-PA was expressed at a high level in normal cells, but was significantly inhibited in group B. The effect of IL-18 was significantly attenuated in group C (Table VIII, Figs. 16 and 17).

Results of RT-qPCR analysis of endothelial cell-related markers. Compared with normal cells in the group $\mathrm{A}$, the expression levels of $\mathrm{vWF}$ and $\mathrm{P}$-selectin were upregulated $(\mathrm{P}<0.05)$ and the expression of t-PA was downregulated $(\mathrm{P}<0.005)$ in group $\mathrm{B}$. There were no significant differences the expression levels of $\mathrm{vWF}, \mathrm{P}$-selectin and t-PA between group $\mathrm{C}$ and group $\mathrm{A}(\mathrm{P}>0.05)$ (Table IX and Fig. 18).

\section{Discussion}

IL-18 is expressed in a variety of cells in the body, and is mainly involved in the regulation of inflammatory and immune reactions. It is also important in the release and interaction of proinflammatory cytokines. Endothelial cells act as key targets of immune and inflammatory mediators in the circulating system. Morel et al (9) confirmed that IL-18 promoted the expression levels of E-selectin, vascular cell adhesion protein-1 and other adhesion molecules in dermal microvascular endothelial cells. These have important effects on inflammatory-related diseases, including rheumatoid arthritis, and may be involved through activating $\mathrm{NF}-\kappa \mathrm{B}$ or phosphatidylinosde 3-kinase cell signaling pathways. A study by Chandrasekar et al (3) on cardiovascular diseases revealed that IL-18 activated the NF- $\mathrm{B}$-mediated signal transduction pathway, which in turn activated cardiac microvascular endothelial cell apoptotic signaling, and led to the growth and 

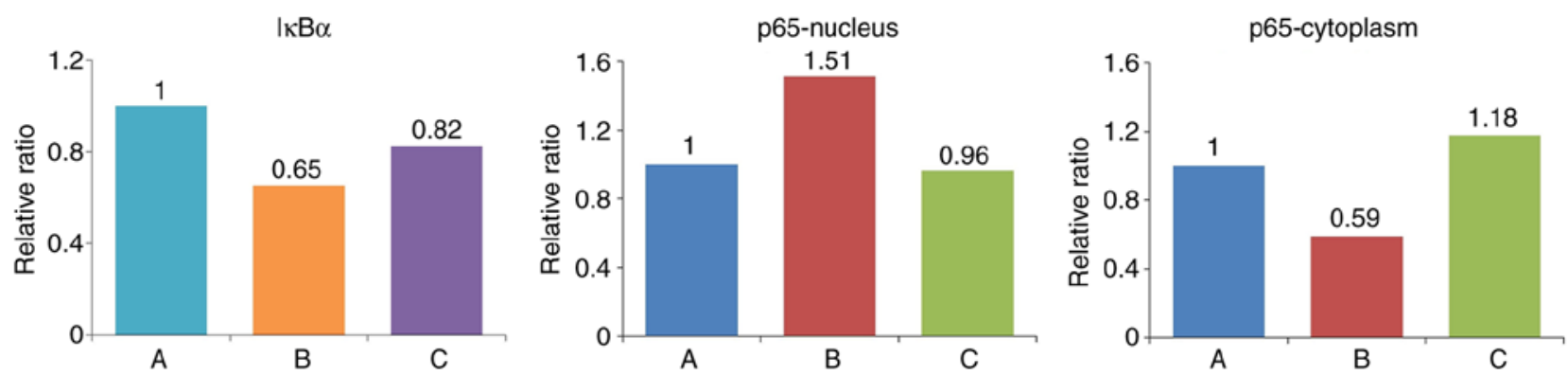

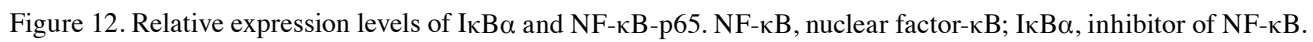

(200x)

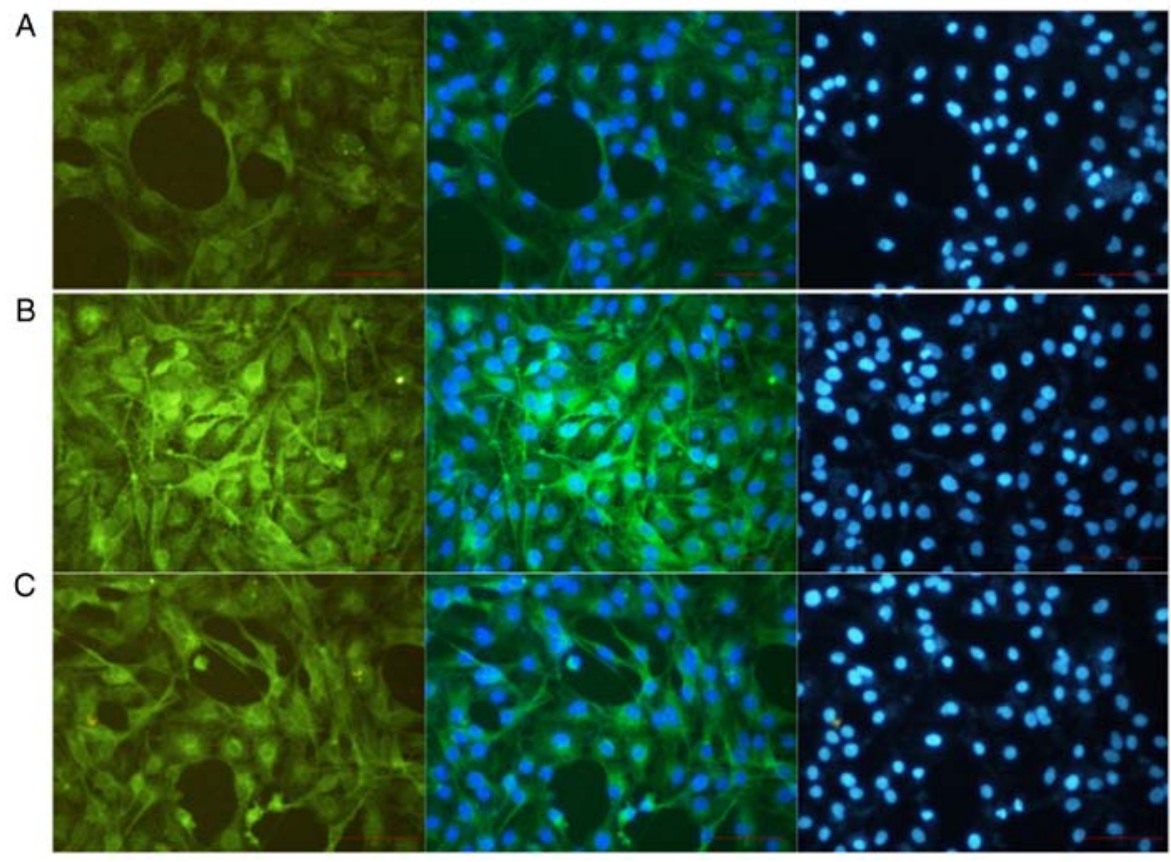

Figure 13. Immunofluorescence results. FITC-labeled secondary antibody appeared as green fluorescence following binding to p-p65. The nucleus appeared as blue fluorescence following DAPI staining (magnification, x200). A, control; B, IL-18 treatment; C, IL-18+QNZ treatment.

functional abnormalities of endothelial cells. This suggested that IL-18 was involved through NF- $\mathrm{KB}$ signal transduction pathway activation, rather than relying on IL- $1 \beta$, tumor necrosis factor- $\alpha$ and interferon- $\gamma$ to induce the death of HCMECs. In the present study, it was found that IL-18, NF- $\kappa B$ and vWF were expressed at high levels in the rat model, and that upregulation of the expression of IL-18 using viral vectors increased the severity of thrombophilia and thrombosis, leading to increased expression levels of NF- $\mathrm{KB}$ and $\mathrm{vWF}$. Baker et al (10) found that the sustained activation of NF- $\mathrm{KB}$ remained harmful, and triggered a series of chronic inflammatory processes by promoting the expression of inflammatory factors, subsequently resulting in cell damage and induction of diseases. Therefore, the present study hypothesized that IL-18 in venous thrombosis can activate NF- $\mathrm{\kappa B}$ to induce abnormalities in cell growth and functional status, and is important in the formation of DVT.

In the present study, recombinant human IL-18 was used added to the HUVECs cultured in vitro, and induced significant changes in the expression levels of NF- $\mathrm{kB}-\mathrm{p} 65$. In the cell resting state, $\mathrm{NF}-\kappa \mathrm{B}$ is located in the cytoplasm in a non-active form. In the activated state, the p65-p50 dimer and Iк $\mathrm{B} \alpha$ are isolated and transferred to the nucleus, where they are involved in activating intracellular signaling pathways and the transcription of target gene. The isolated IкB $\alpha$ ultimately undergoes proteolysis. When the conditions change, the activator may produce new I $\kappa \mathrm{B} \alpha$ and then move into the nucleus. It then separates NF- $\kappa B$ from DNA and reconstitutes into the p65-p50-IкB $\alpha$ complex to move back into the cytoplasm $(11,12)$. The expression of $\mathrm{p} 65$ in the nucleus of the HUVECs was significantly upregulated following treatment with IL-18, whereas expression in the cytoplasm was significantly decreased compared with that in normal cells. This further confirmed that IL-18 effectively activated NF- $\kappa B$ in the dissociation of p65-p50-IкB $\alpha$, and that the p65-p50 dimer was rapidly transferred into the nucleus to induce its corresponding effect. The expression of p65 in the nucleus was downregulated by using the NF- $\mathrm{KB}$ activator, inhibitor QNZ, and its relative expression in the cytoplasm was close to that in the normal cells. This revealed that the activation of NF- $\kappa B$ by IL-18 produced large quantities of phosphorylated p65-p50 dimers and then migrated into the nucleus, which was 


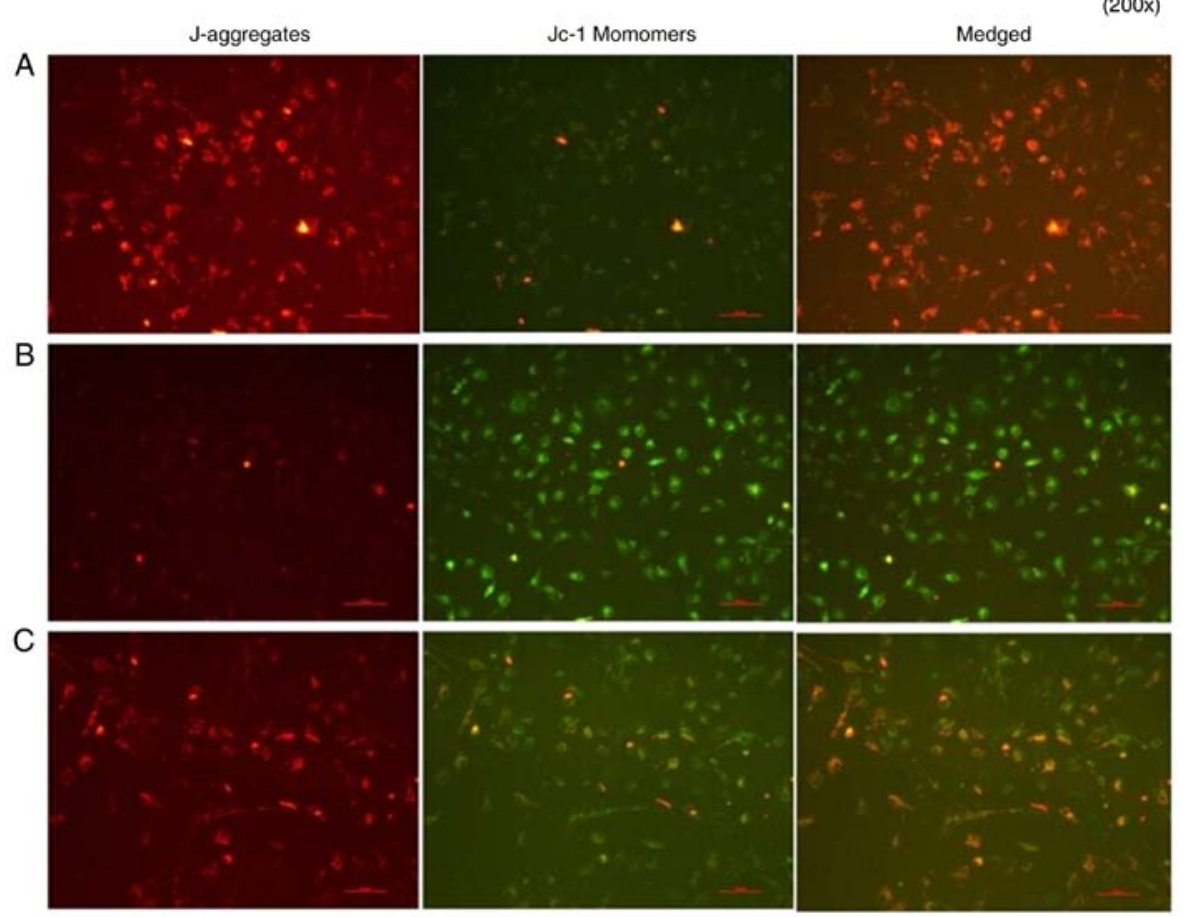

Figure 14. Results of the mitochondrial membrane potential assay. A, control; B, interleukin-18 treatment; C, interleukin-18+QNZ treatment. Magnification, x200.
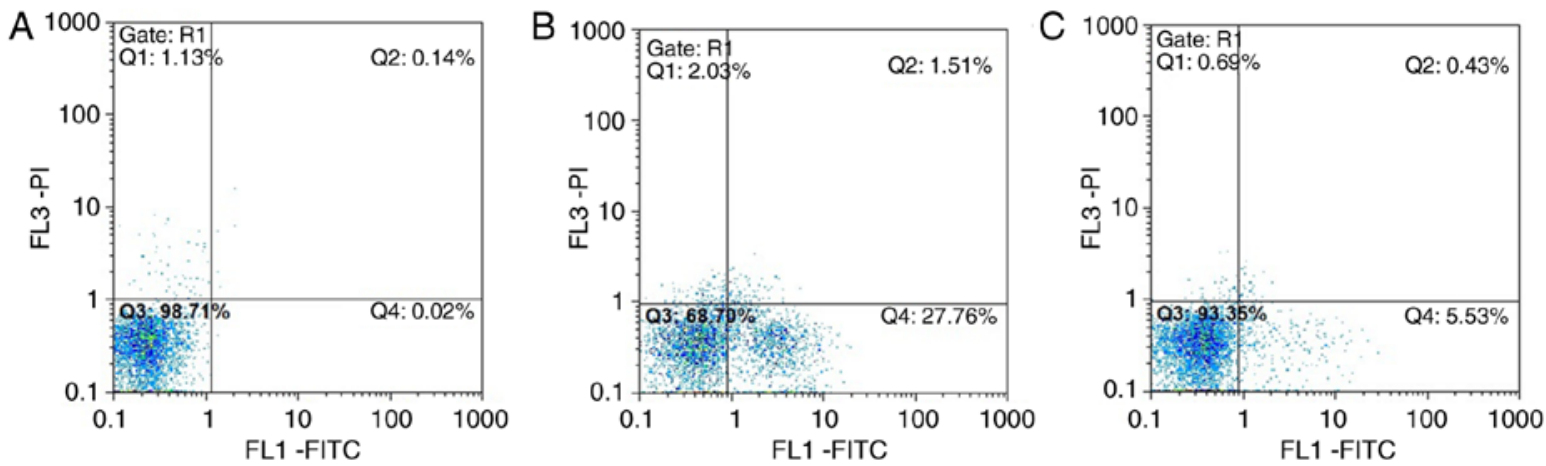

Figure 15. Annexin V-FITC/PI flow cytometry results. Q1, testing error within the permissible range, which is practically insignificant; Q2, late apoptotic and necrotic cells; Q3, normal viable cells; Q4, early apoptotic cells. A, control; B, interleukin-18 treatment; C, interleukin-18+QNZ treatment.

significantly suppressed following the application of QNZ. Several studies involving cell and animal models (13-15) have demonstrated that QNZ effectively suppresses the activation of NF-kB-mediated intracellular signal transduction pathway and target gene transcription.

Thrombotic disease is a common complication occurring during orthopedic surgery and trauma. Arterial thrombosis and embolization occur rarely. More commonly, DVT and pulmonary embolism are important factors, which may affect the perioperative treatment and increase mortality rates. In the 1850s, Virchow described three factors of venous thrombosis, which included blood stagnation, hypercoagulable state and vein wall damage, and these remain publicly recognized. With the progression of thrombotic disease-related studies, it is increasingly considered that endothelial cell injury, the adhesion, aggregation and release of platelets, and activation of soluble coagulation factors are three independent elements of equal significance (16). Endothelial cells are important

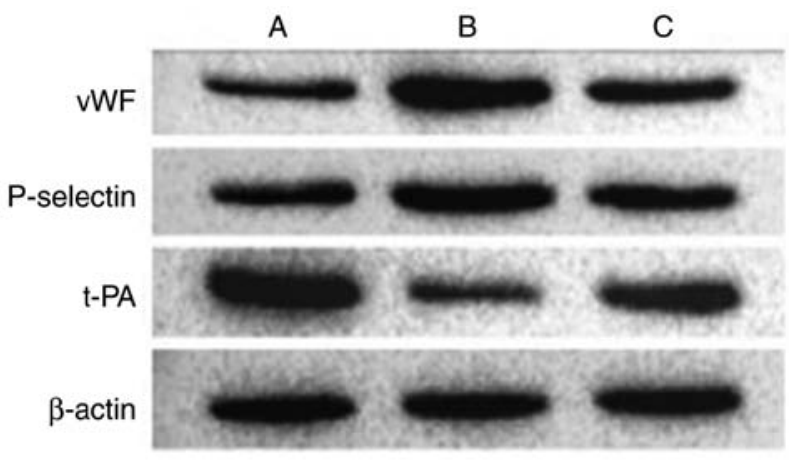

Figure 16. Protein expression of vWF, P-selectin and t-PA in different treatment groups. A, control; B, interleukin-18 treatment; C, interleukin-18+QNZ treatment. vWF, von Willebrand factor; t-PA, tissue plasminogen activator.

in the pathogenesis of thrombotic diseases as they regulate physiological anticoagulation and pathological thrombosis. 

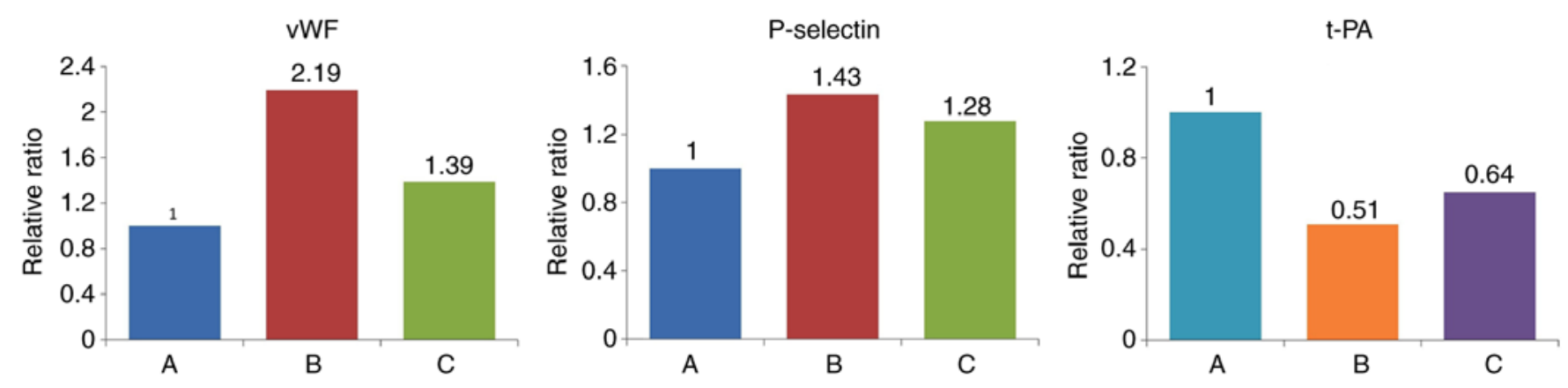

Figure 17. Expression levels of vWF, P-selectin and t-PA. Compared with group A, the expression levels of vWF and P-selectin were significantly increased and the expression of t-PA was significantly decreased in group B. Expression levels of vWF, P-selectin and t-PA in group C were similar to those in normal cells. A, control; B, interleukin-18 treatment; C, interleukin-18+QNZ treatment. vWF, von Willebrand factor; t-PA, tissue plasminogen activator.
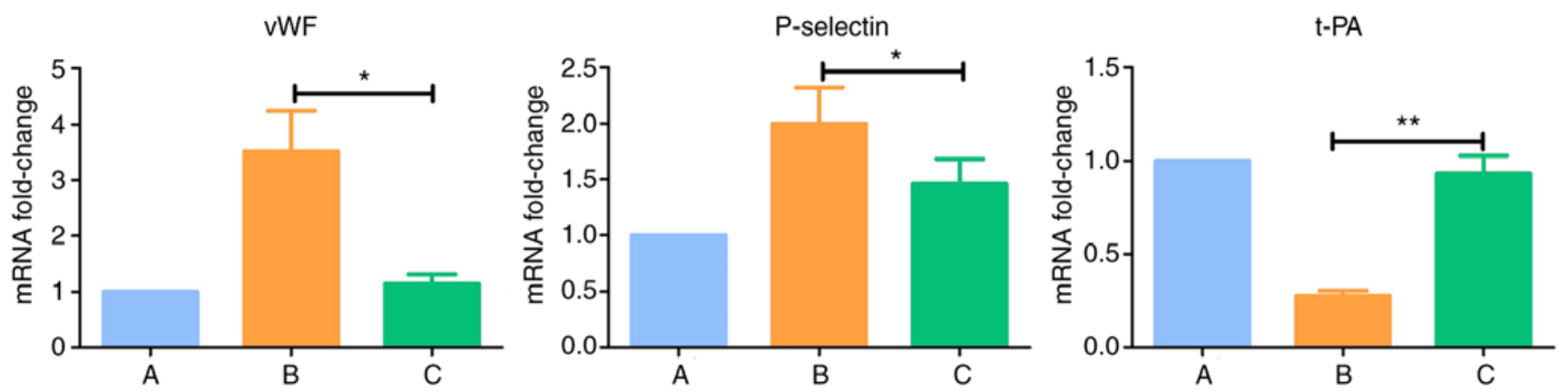

Figure 18. Intergroup comparisons of vWF, P-selectin and t-PA. A, control; B, interleukin-18 treatment; C, interleukin-18+QNZ treatment. vWF, von Willebrand factor; t-PA, tissue plasminogen activator. ${ }^{*} \mathrm{P}<0.05$ and ${ }^{* *} \mathrm{P}<0.005$.

In the present study, a large number of HUVECs showed decreased abnormal status of mitochondrial membrane potential following the application of IL-18. Annexin V-FITC/PI flow cytometry revealed that a large number of cells were early apoptotic, and the numbers of late apoptotic and necrotic cells were also increased compared with those in the normally-cultured cells. Previous studies $(17,18)$ have confirmed that the abnormal expression of inflammatory factors cause changes in endothelial cell apoptosis, leading to vascular wall injury. This ultimately promotes the formation of local blood clots and further stimulates inflammatory cell infiltration, thereby resulting in abnormal progression of thrombosis and atherosclerotic plaques. Apoptosis remains the main process for maintaining a steady state of cell population under normal conditions. However, the rapid or abnormal apoptosis of cells lead to changes in the normal cell function and can lead to diseases. In the present study, following application of the $\mathrm{NF}-\kappa \mathrm{B}$ activation inhibitor QNZ, the number of normal viable cells, viable apoptotic cells, non-viable apoptotic and necrotic cells were similar to those in the normal group. This further confirmed that IL-18 induced abnormal growth of HUVECs and increased the number of viable apoptotic cells, which was significantly improved by inhibiting the activation of NF- $\mathrm{BB}$.

In the present study, the endothelial cell dysfunction markers, vWF, P-selectin and t-PA, were altered following treatment of the HUVECs with IL-18. vWF is a type of macromolecular glycoprotein, which is synthesized primarily by vascular endothelial cells. The synthesized and secreted vWF is increased when endothelial cells are damaged or stimulated, which promotes the adhesion of platelets and binds with GPIb and subcutaneous collagen. It is also involved in the formation of emboli and platelets at the injured site in endothelial cells (19). It also can produce complexes by binding with plasma VIII factor to prevent its degradation and protect its activity. Studies have found $(20,21)$ that the expression of vWF is upregulated in patients at high risk of atherosclerosis, which is also considered a marker of endothelial injury. The results of the present study also confirmed that the upregulation of IL-18 activated NF- $\kappa \mathrm{B}$-induced HUVEC dysfunction and increased the expression of vWF. This in turn altered the coagulation property in the venous lumen, leading to thrombophilia. Vascular endothelial cells can synthesize P-selectin, which is stored in Weibel-Palade bodies. When endothelial cells are dysfunctional or stimulated, the Weibel-Palade bodies fuse with the cell membrane. P-selectin is a membrane glycoprotein, which is present on the cell surface and acts as a receptor for neutrophils and monocytes, mediating the interactions between endothelial cells, platelets and leukocytes. Therefore, P-selectin is often used as a marker of endothelial dysfunction. The increased expression of P-selectin can lead to the occurrence of thrombophilia, inducing the activation of procoagulants and formation of fibrin $(22,23)$. Studies $(7,24)$ have revealed that P-selectin has a significant effect on thrombosis, where the upregulation of soluble P-selectin in the blood can be used as a clinical risk factor in venous thrombosis. Treatment of the HUVECs with IL-18 significantly increased the expression of P-selectin, unlike vWF, and its abnormal expression was effectively suppressed following inhibition of the activation of $\mathrm{NF}-\kappa \mathrm{B}$. Physiologically, thrombosis requires prompt removal to restore the patency of the vein. Therefore, 
there is a complex fibrinolytic system in the body, including plasminogen, plasmin inhibitor, plasminogen activator and plasminogen activator inhibitor. Endothelial cells can synthesize t-PA and urokinase-type plasminogen activator (u-PA). Of these, t-PA has a higher affinity to fibrin. Following fibrin formation, t-PA and plasminogen in the emboli bind to the fibrin. The t-PA can activate the plasminogen present on the fibrin surface, having a fibrinolytic effect locally (25). Recombinant t-PA synthesized by genetic engineering has been used as an antithrombotic drug (24). In the present study, it was found that IL-18 led HUVECs to produce t-PA, which significantly improved following the application of inhibitors of $\mathrm{NF}-\kappa \mathrm{B}$ activation. These results demonstrated that IL-18 activated $\mathrm{NF}-\kappa \mathrm{B}$ causing the dysfunction of venous endothelial cells, which may in turn act as one of the most important pathways for demonstrating the mechanism of association between IL-18 and DVT formation.

In conclusion, IL-18, in addition to NF- $\kappa \mathrm{B}$ and $\mathrm{vWF}$, are closely associated with DVT, and regulation of the expression of IL-18 can alter NF- $\kappa$ B, vWF and other related markers. A high expression of IL-18 can activate NF- $\mathrm{NB}$, causing damage, apoptosis and other changes of the venous endothelial cells. This in turn leads to cell dysfunction, further affecting the endothelial cells and causing abnormal changes in thrombotic disease-related cell function markers, vWF, P-selectin and t-PA. The mechanism underlying DVT is complicated. IL-18 was shown to be involved in the regulation of inflammatory and immune reactions in vivo, and regulated the expression of $\mathrm{NF}-\kappa \mathrm{B}$ and $\mathrm{vWF}$, but also affected endothelial function. This may be one of the important mechanisms involved in DVT. The association between IL-18 and related markers and DVT requires further detailed investigation, including the examination of platelets, erythrocytes, leukocytes, fibrinolytic abnormalities and anti-procoagulant abnormalities.

\section{Acknowledgements}

Not applicable.

\section{Funding}

This study was supported by the National Natural Science Foundation of China Science Fund Project (grant nos. 30960389 and 8176010097), the Guizhou Province Science and Technology Program Joint Fund Project [grant no. Qian Ke He LH Zi (2016) no. 7228] and the Guizhou Medical University Doctoral Start Fund Project [grant no. Yuan Bo He J Zi (2015) 019].

\section{Availability of data and materials}

The datasets used and/or analyzed during the current study are available from the corresponding author on reasonable request.

\section{Authors' contributions}

GL and XZ made substantial contributions to the conception of the present study. GL drafted and wrote the manuscript preparation and performed the data analyses. RZ generated overexpression and suppression vectors employed in the present study. RL and
CY made substantial contributions to data analysis and critically revised the manuscript for important intellectual content.

\section{Ethics approval and consent to participate}

All animal experiments were performed following approval from the Animal Experiment and Ethics Committee of Kunming Medical University (Kunming, China).

\section{Consent for publication}

Not applicable.

\section{Competing interests}

The authors declare that they have no competing interests.

\section{References}

1. Downing LJ, Strieter RM, Kadell AM, Wilke CA, Austin JC, Hare BD, Burdick MD, Greenfield LJ and Wakefield TW: IL-10 regulates thrombus-induced vein wall inflammation and thrombosis. J Immunol 161: 1471-1476, 1998.

2. Strukova S: Blood coagulation-dependent inflammation. Coagulation-dependent inflammation and inflammation-dependent thrombosis. Front Biosci 11: 59-80, 2006.

3. Chandrasekar B, Vemula K, Surabhi RM, Li-Weber M, Owen-Schaub LB, Jensen LE and Mummidi S: Activation of intrinsic and extrinsic proapoptotic signaling pathways in interleukin-18-mediated human cardiac endothelial cell death. J Biol Chem 279: 20221-20233, 2004.

4. Li YD, Ye BQ, Zheng SX, Wang JT, Wang JG, Chen M, Liu JG, Pei XH, Wang LJ, Lin ZX, et al: NF-kappaB transcription factor p50 critically regulates tissue factor in deep vein thrombosis. J Biol Chem 284: 4473-4483, 2009.

5. Brill A, Fuchs TA, Chauhan AK, Yang JJ, De Meyer SF, Köllnberger M, Wakefield TW, Lämmle B, Massberg S and Wagner DD: Von Willebrand factor-mediated platelet adhesion is critical for deep vein thrombosis in mouse models. Blood 117: 1400-1407, 2011

6. Livak KJ and Schmittgen TD: Analysis of relative gene expression data using real-time quantitative PCR and the 2(-delta delta $\mathrm{C}(\mathrm{T}))$ method. Methods 25: 402-408, 2001.

7. Myers DD, Hawley AE, Farris DM, Wrobleski SK, Thanaporn $P$, Schaub RG, Wagner DD, Kumar A and Wakefield TW: P-selectin and leukocyte microparticles are associated with venous thrombogenesis. J Vasc Surg 38: 1075-1089, 2003.

8. Henke PK, Varga A, De S, Deatrick CB, Eliason J, Arenberg DA, Sukheepod P, Thanaporn P, Kunkel SL, Upchurch GR Jr and Wakefield TW: Deep vein thrombosis resolution is modulated by monocyte CXCR2-mediated activity in a mouse model. Arterioscler Thromb Vasc Biol 24: 1130-1137, 2004.

9. Morel JC, Park CC, Woods JM and Koch AE: A novel role for interleukin-18 in adhesion molecule induction through NF kappa B and phosphatidylinositol (PI) 3-kinase-dependent signal transduction pathways. J Biol Chem 276: 37069-37075, 2001

10. Baker RG, Hayden MS and Ghosh S: NF-kappaB, inflammation, and metabolic disease. Cell Metab 13: 11-22, 2011.

11. Oeckinghaus A, Hayden MS and Ghosh S: Crosstalk in NF- $\kappa \mathrm{B}$ signaling pathways. Nat Immunol 12: 695-708, 2011.

12. Sen R: The origins of NF-kB. Nat Immunol 12: 686-688, 2011.

13. Tobe $M$, Isobe $Y$, Tomizawa $H$, Nagasaki T, Takahashi $H$ and Hayashi H: A novel structural class of potent inhibitors of NF-kappa B activation: Structure-activity relationships and biological effects of 6-aminoquinazoline derivatives. Bioorg Med Chem 11: 3869-3878, 2003.

14. Armstrong SJ, Wiberg M, Terenghi G and Kingham PJ: Laminin activates NF-kappaB in Schwann cells to enhance neurite outgrowth. Neurosci Lett 439: 42-46, 2008.

15. Yang RH, Strong JA and Zhang JM: NF-kappaB mediated enhancement of potassium currents by the chemokine CXCL1/growth related oncogene in small diameter rat sensory neurons. Mol Pain 5: 26, 2009. 
16. Blann AD and Lip GY: Virchow's triad revisited: The importance of soluble coagulation factors, the endothelium, and platelets. Thromb Res 101: 321-327, 2001.

17. Pan J, Zhang SQ and Chen B: Interferon- $\gamma$ induces the apoptosis of vascular endothelial cell in vitro. J Bengbu Med Coll 30: 388-389, 2005.

18. Choy JC, Granville DJ, Hunt DW and McManus BM: Endothelial cell apoptosis: Biochemical characteristics and potential implications for atherosclerosis. J Mol Cell Cardiol 33: 1673-1690, 2001.

19. Blann AD: Plasma von Willebrand factor, thrombosis, and the endothelium: The first 30 years. Thromb Haemost 95: 49-55, 2006.

20. Jansson JH, Nilsson TK and Johnson O: Von Willebrand factor in plasma: A novel risk factor for recurrent myocardial infarction and death. Br Heart J 66: 351-355, 1991.

21. Cortellaro M, Boschetti C, Cofrancesco E, Zanussi C, Catalano M, de Gaetano G, Gabrielli L, Lombardi B, Specchia G and Tavazzi L: The PLAT Study: Hemostatic function in relation to atherothrombotic ischemic events in vascular disease patients. Principal results. PLAT Study Group. Progetto Lombardo Atero-Trombosi (PLAT) Study Group. Arterioscler Thromb 12 1063-1070, 1992.
22. Cambien B and Wagner DD: A new role in hemostasis for the adhesion receptor P-selectin. Trends Mol Med 10: 179-186, 2004.

23. Furie B and Furie BC: Role of platelet P-selectin and microparticle PSGL-1 in thrombus formation. Trends Mol Med 10. 171-178, 2004.

24. Rosenbaum T, Rammos S, Kniemeyer HW and Gobel U: Extended deep vein and inferior vena cava thrombosis in a 15-year-old boy: Successful lysis with recombinant tissue-type plasminogen activator 2 weeks after onset of symptoms. Eur J Pediatr 152: 978-980, 1993.

25. Kruithof EK and Dunoyer-Geindre S: Human tissue-type plasminogen activator. Thromb Haemost 112: 243-254, 2014.

(i)(9) This work is licensed under a Creative Commons Attribution-NonCommercial-NoDerivatives 4.0 International (CC BY-NC-ND 4.0) License. 